\title{
IR - spectroscopic characterization of biominerals in marattiaceaeus ferns
}

\author{
ENRIQUE J. BARAN ${ }^{1,3}$ and CRISTINA H. ROLLERI ${ }^{2}$
}

(received: April 17, 2008; accepted: July 01, 2010)

\begin{abstract}
IR - spectroscopic characterization of biominerals in marattiaceaeus ferns). Frond samples of the eusporangiate ferns Marattiaceae genera Angiopteris, Christensenia, Danaea and Marattia were investigated by infrared spectroscopy, under different experimental conditions. The results confirmed the previously reported accumulation of biogenic silica $\left(\mathrm{SiO}_{2}\right)$ in tissues of these ferns and also showed, for the first time, the presence of calcium oxalate in this group of plants, probably as weddellite. The ability to biomineralize $\mathrm{SiO}_{2}$, to produce and accumulate biogenic silica, is suggested now to be a general family trait of the Marattiaceae.
\end{abstract}

Key words - biogenic silica, calcium oxalate, Marattiaceae

RESUMO - (Caracterização de biominerais por espectroscopia infravermelha em Marattiaceae). Mostras de frondes dos fetos eusporangiados dos gêneros Angiopteris, Christensenia, Danaea e Marattia (Marattiaceae), foram investigadas por espectroscopia infravermelha sob diferentes condições experimentais. Os resultados confirmaram relatos anteriores sobre a acumulação de sílica biogênica $\left(\mathrm{SiO}_{2}\right)$, em tecidos desses fetos e também mostraram, pela primeira vez, a presença de oxalato de cálcio nesse grupo de plantas, provavelmente na forma de weddellite. A capacidade de mineralizar $\mathrm{SiO}_{2}$, para produzir e acumular sílica biogênica, sugere que esta característica seja uma propriedade genérica dos membros da família Marattiaceae.

Palavras-chave - Marattiaceae, oxalato de cálcio, silica biogênica

\section{Introduction}

The presence and wide distribution of biogenic silica $\left(\mathrm{SiO}_{2}\right.$, opal) in the plant kingdom is well known (Blackman 1971, Bertoldi de Pomar 1975, Arnott 1982, Perry 1989, 2003, Monje \& Baran 2004).

Silica bodies are found in cells of leaves and other parts of the plant body in several groups of vascular plants, such as Equisetaceae and Hymenophyllaceae, among the Pteridophyta, or as in genera and species of many angiospermous families, such as Aristolochiaceae, Loranthaceae,Podostemaceae,Cannaceae,Commelinaceae, and Poaceae (Haberlandt 1965), the latter being the most studied group due to the diversity of morphological cell types involved in the accumulation of silica.

Ferns are a group with scarce studies related to silica bodies. Recently, one of us has performed systematic

1. Universidad Nacional de La Plata, Facultad de Ciencias Exactas, Centro de Química Inorgánica (Cequinor/Conicet,UNLP), Casilla de Correo 962, 1900 La Plata, Argentina.

2. Facultad de Ciencias Naturales y Museo de La Plata, Laboratorio de Estudios de Anatomía Vegetal Evolutiva y Sistemática (Leaves), 64 entre 120 y diagonal 113, B1904 DZB La Plata, Argentina.

3. Corresponding author: baran@quimica.unlp.edu.ar analyses of the $\mathrm{SiO}_{2}$ accumulation in eusporangiate ferns belonging to the Marattiaceae Bercht. \& J. S. Pres1 (Rolleri 1993, 2002, 2003, Rolleri et al. 1987, 1991, 2003, 2004). These studies were carried out through microchemical analysis using the phenol test (Johansen 1940), and also using polarized light microscopy to calculate mineralogical constants. They demonstrated that three of the five marattiaceous genera, Angiopteris Hoffm., Archangiopteris H. Christ \& Giensenh. and Marattia Sw. always have opal idioblasts in the epidermis of lamina of pinnae, pinnulae or segments, and also in cells of the inner parenchymatose tissues. The other two genera, Christensenia Maxon and Danaea Sm., lack of specialized epidermal cells with opal inclusions (Rolleri et al. 2003).

Most species belonging to the five genera were also investigated by means of scanning electron microscopy and EDAX microanalysis (Rolleri et al. 2004). These studies clearly confirmed the presence of opal deposits, distributed in a variety of ways in all studied specimens. Conclusions made was that opal is accumulated preferentially in the epidermal cells of the fronds, but can also be found, as smaller inclusions, within parenchymatose cells near vascular bundles of 
axes and laminae. Besides, although opal is absent in the epidermal cells of Christensenia and Danaea, all species of both genera bear small amounts of amorphous silica inclusions within the parenchymatose tissues of axes and fronds.

The previous studies point to the fact that, no matter where is the silica finally accumulated, all the marattiaceous genera may produce it, either abundant and easily detected, as reported for Angiopteris, Archangiopteris and Christensenia, or as small isolated silica bodies, more or less dispersed in the internal tissues of the plant body. Thus, the aim of the present work was to advance into a wider physicochemical characterization of these bioinorganic deposits by performing an infrared spectroscopic study of several species of the genera of the marattiaceous ferns, in order to attain more accurate information on the silica bodies present in genera with and without epidermal idioblasts.

\section{Material and methods}

Plant material - The following species were selected for analysis: Angiopteris evecta (Forst.) Hoffm., A. pruinosa Kunze, Christensenia aesculifolia (B1.) Maxon subsp. aesculifolia, C. aesculifolia (B1.) Maxon subsp. P. korthalsii (de Vriese) Rolleri, Danaea nodosa (L.) Sm., D. moritziana C. Presl, Marattia laevis Sm., M. sylvatica (B1.), and $M$. weinmanifolia Liebm. They came from herborized specimens obtained from not poisoned material of the U.S. National Herbarium. Samples were taken from plants collected in different locations of the geographical area of each species. A detailed citation list of specimens under study can be found in Rolleri et al. (2004).

Treatment of plant material - The plant samples were treated as follows before their spectra were recorded: a) dry material was pulverized in a vibrating mill during different periods of time, up to 15 hours, using agate sample holders and balls; b) the manually dispersed, dry material, was heated in a muffle furnace in air, at different temperatures, up to $400^{\circ} \mathrm{C}$, as described by Lanning et al. (1958); c) the dry material was treated with concentrated nitric acid and carefully heated over a water bath in air, as described by Kamatani (1971).

Infrared spectra - The spectra were recorded on a FTIRBruker IF66 spectrophotometer in the range between 4000 and $400 \mathrm{~cm}^{-1}$, using the $\mathrm{KBr}$ pellet technique ( $\mathrm{ca} .4 \mathrm{mg}$ of the powdered sample dispersed in $100 \mathrm{mg}$ of $\mathrm{KBr}$ ) (Drago 1965, Baran 2005). The experiments performed with each sample of all the investigated fern taxa showed a similar behavior. Since all IR spectra resulted comparable, and only minor differences in relative band intensities were observed, only those obtained with the $A$. pruinosa sample were illustrated in detail.
Terminology - The chemical and spectroscopic terminology was taken from Baran $(1995,2005)$ and Monje \& Baran (2004), terms on ferns come from Rolleri et al. (1991, 2004) and Lellinger (2002).

\section{Results}

The IR spectrum of a sample milled during 15 hours, is shown in figure 1A for the most interesting spectral range between 2000 and $450 \mathrm{~cm}^{-1}$. The intense band located at $1641 \mathrm{~cm}^{-1}$ is characteristic of calcium oxalate (corresponding to the antisymmetric oxalate stretching mode (Monje \& Baran 1996, 1997)). The corresponding symmetric stretching is probably the weak band found at $1340 \mathrm{~cm}^{-1}$ partially overlapped by the unidentified medium intensity band centered at $1427 \mathrm{~cm}^{-1}$. The other strong band, centered at $1072 \mathrm{~cm}^{-1}$ is one of the characteristic biogenic silica bands (Kamatani 1971, Perry 1989). The remaining broad feature located between 850 and $450 \mathrm{~cm}^{-1}$ includes both unresolved oxalate and silica bands. In the higher frequency side of the spectrum (not shown) a very broad and undefined band, centered at about $3380 \mathrm{~cm}^{-1}$ is observed. This band is related to $\mathrm{O}-\mathrm{H}$ stretching modes of water and of $\mathrm{Si}-\mathrm{OH}$ groups.

Crystalline calcium oxalates have been found in two different hydration states in plants, either as the monohydrate (whewellite, $\mathrm{CaC}_{2} \mathrm{O}_{4} \cdot \mathrm{H}_{2} \mathrm{O}$ ) or as the dihydrate (weddellite, $\mathrm{CaC}_{2} \mathrm{O}_{4} \cdot 2 \mathrm{H}_{2} \mathrm{O}$ ) (Arnott 1982, Monje \& Baran 2004; Baran \& Monje 2008). Unfortunately, it was not possible to arrive to an unambiguous identification of the chemical nature of the calcium oxalate found in these plants On the basis of the only relatively well defined oxalate IR band (located at $1641 \mathrm{~cm}^{-1}$ in the $A$. pruinosa sample and between 1641 and $1658 \mathrm{~cm}^{-1}$ in the spectra of the other species) one could tentatively suggest the presence of weddellite (pure weddelite band is found at $1645 \mathrm{~cm}^{-1}$ whereas in whewellite it is found at $1622 \mathrm{~cm}^{-}$ ${ }^{1}$ (Monje \& Baran, 1996, 1997)). Furthermore, the low frequency spectral range which usually allows a clear differentiation between the two calcium oxalate forms (Monje \& Baran 2002), appears partially overlapped by one of the typical $\mathrm{SiO}_{2}$ bands and is highly undefined.

A clearly different IR spectrum was obtained when one of the milled samples, or a dry sample of the plant material, was slowly heated in a muffle furnace up to $400{ }^{\circ} \mathrm{C}$ and then maintained for 2 hours at this temperature (figure 1B). This spectrum shows the presence of calcite (bands at 1450 (antisymmetric stretching, $v_{3}$ ), 876 (out 

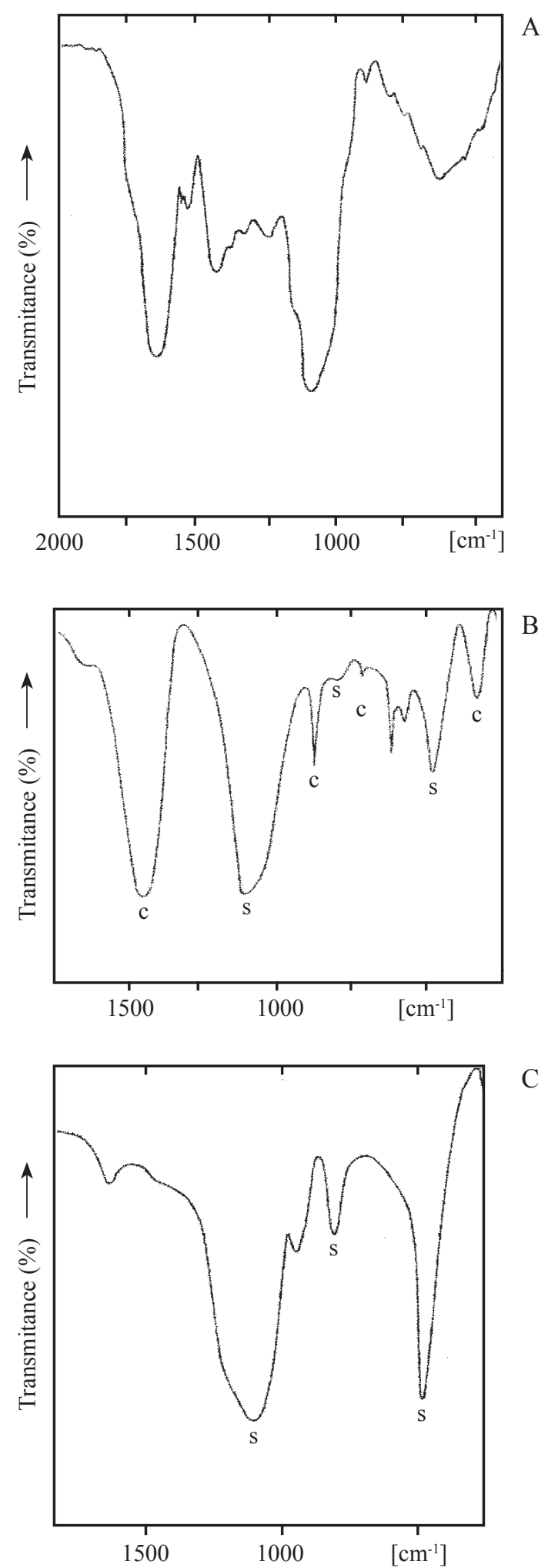

Figure 1. A. FTIR spectrum of a powdered sample of Angiopteris pruinosa dry fronds. B. FTIR spectrum of dry fronds of Angiopteris pruinosa heated during $2 \mathrm{~h}$ at $400{ }^{\circ} \mathrm{C}$. C. FTIR spectrum of a heated sample, after treatment with $\mathrm{HCl}$. (band identification: $\mathrm{C}=$ calcite bands; $\mathrm{S}=\mathrm{SiO}_{2}$ (opal) bands). of plane deformation, $v_{2}$ ), 714 (in plane deformation, $v_{4}$ ) and 326 (lattice mode) $\mathrm{cm}^{-1}$ (Ross 1972)) and biogenic silica (bands at 1100, 796 and $476 \mathrm{~cm}^{-1}$ (Kamatani 1971, Perry 1989)).

This thermally generated product was treated with diluted $\mathrm{HCl}$, then washed several times with distilled water and dried at $100{ }^{\circ} \mathrm{C}$. The recorded IR spectrum of this new sample, shown in figure $1 \mathrm{C}$, is different from that found in figure 1B and only the three characteristic absorptions of biogenic silica, together with a weak unidentified feature at $941 \mathrm{~cm}^{-1}$, remain in the spectrum. This spectrum is identical to those measured in other biogenic silica samples (Kamatani 1971).

It is noteworthy the fact that after heating the milled sample at $200{ }^{\circ} \mathrm{C}$ during short periods of time the spectra show oxalate, carbonate, and silica bands. Besides, the treatment of the plant material with nitric acid generates a solid which IR spectrum presents only the characteristic opal bands. It become evident that organic matter, together with the oxalate deposits, are both destroyed during the treatment with a strong oxidizing acid, and only $\mathrm{SiO}_{2}$, a species which is stable in acidic media, is fully recovered.

\section{Discussion}

The performed spectroscopic study confirms, in an independent way, the previously established existence of opal deposits in marattiaceous ferns. These measurements also show, for the first time, the presence of calcium oxalate in ferns. The presence of this biomineral is additionally supported by the chemical behavior of the investigated material. The heating of a calcium oxalate/ opal mixture generates calcite, whereas opal remains unchanged, as was spectroscopically observed, and may be due to the following reaction:

$\mathrm{CaC}_{2} \mathrm{O}_{4} \cdot \mathrm{nH}_{2} \mathrm{O}+\mathrm{SiO}_{2} \cdot \mathrm{mH}_{2} \mathrm{O} \rightarrow \mathrm{CaCO}_{3}+\mathrm{CO}+(\mathrm{n}+\mathrm{m}) \mathrm{H}_{2} \mathrm{O}+\mathrm{SiO}_{2}$

The subsequent treatment of the obtained solid residue with $\mathrm{HCl}$, decomposes the generated carbonate:

$$
\mathrm{SiO}_{2}+\mathrm{CaCO}_{3}+2 \mathrm{HCl} \rightarrow \mathrm{SiO}_{2}+\mathrm{CaCl}_{2}+\mathrm{CO}_{2}+\mathrm{H}_{2} \mathrm{O}
$$

and, after the washing, only $\mathrm{SiO}_{2}$ is recovered, as was also spectroscopically confirmed.

The heating of the plant material at lower temperatures and for short periods of time generates a mixture which contains part of the original biominerals together with $\mathrm{CaCO}_{3}$, which is produced by the partial decomposition of the oxalate. 
Although it was not possible to identify unambiguously the chemical nature of the calcium oxalate accumulated by these ferns, weak evidence derived from the position of the antisymmetric oxalate stretching vibration points out to the presence of weddellite, $\left(\mathrm{CaC}_{2} \mathrm{O}_{4} \cdot 2 \mathrm{H}_{2} \mathrm{O}\right)$.

The ability to biomineralize $\mathrm{SiO}_{2}$ and to produce opal was considered a diagnostic trait only at the generic level in the Marattiaceae (Rolleri et al. 2003, 2004), but after the results of the present study we suggest to consider it a family character, shared by all five genera. While the distribution of epidermal idioblasts in Angiopteris, Archangiopteris and Marattia varies from solitaire, groups from 2 to 6 idioblasts, or extensive groups of these cells containing opal (idioblast areas, Rolleri et al. 2003), the cells of soft tissues near costae and secondary veins of pinnae of species belonging to all genera bear isolated, generally small, silica bodies. These bodies were previously observed through longitudinal and transversal sections of axes and pinnae, and also after clearing the foliar tissues of laminae. The now performed IR spectroscopic study confirms that these bodies are also $\mathrm{SiO}_{2}$ inclusions. The internal amorphous crystals are smaller than those accumulated in the epidermis, and more difficult to be observed than the epidermal silica, mostly composed of inclusions as large as the idioblasts themselves. Since all genera also have opal in scattered cells of inner parenchymatous tissues, specially in those situated close to the vascular bundles, the results obtained by IR spectroscopy confirm one of the outstanding characters of the family.

Acknowledgements - The authors are indebted to Dr. David Lellinger, formerly Curator of Ferns of the U.S. National Herbarium, who gave the authorization to carry out this kind of studies with samples of herbarium material. This work has been supported by the Consejo Nacional de Investigaciones Científicas y Técnicas de la República Argentina (Conicet) and the Universidad Nacional de La Plata. The authors are members of the Research Career of Conicet.

\section{References}

ARNOTT, H.J. 1982. Three systems of biomineralization in plants with comments on the associated organic matrix. In Biological mineralization and demineralization (G.H. Nancollas, ed.). Springer, Berlin, p.199-218.

BARAN, E.J. 1995. Química bioinorgánica, Mc-Graw Hill Interamericana de España S.A., Madrid.

BARAN, E.J. 2005. Applications of vibrational spectroscopy to the investigation of plant material. In Advances in plant physiology (H. Hemantaranjan, ed.). Scientific Publishers, Jodhpur, v.8, p.365-392.
BARAN, E.J. \& MONJE, P.V. 2008. Oxalate biominerals. In Metal ions in life sciences (A. Sigel, H. Sigel \& R.K.O. Sigel, eds.). J. Wiley \& Sons, Chichester, v.4, p.219-254.

BERTOLDI DE POMAR, H. 1975. Los silicofitolitos: sinopsis de su conocimiento. Darwiniana 19:173-206.

BLACKMAN, E. 1971. Opaline silica bodies in the range grasses of southern Alberta. Canadian Journal of Botany 49:769-781.

DRAGO, R.S. 1965. Physical methods in inorganic chemistry, Reinhold Publishing Corporation, New York.

HABERLANDT, G. 1965. Physiological plant anatomy, Today \& Tomorrows Book Agency, New Delhi.

JOHANSEN, D.A. 1940. Plant microtechnique. McGraw-Hill, New York.

KAMATANI, A. 1971. Physical and chemical characteristics of biogenous silica. Marine Biology 8:89-95.

LANNING, F.C., PONNAYA, B.W.X. \& CRUMPTON, C.F. 1958. The chemical nature of silica in plants. Plant Physiology 33:339-343.

LELLINGER, D.B. 2002. A modern multilingual glossary of taxonomic Pteridology. Pteridologia no 3, American Fern Society, Washington.

MONJE, P.V. \& BARAN, E.J. 1996. On the formation of weddellite in Chamaecereus silvestrii, a Cactaceae from northern Argentina. Zeitschrift für Naturforschung 51c: 426-428.

MONJE, P.V. \& BARAN, E.J. 1997. On the formation of whewellite in the Cactaceae species Opuntia microdasys. Zeitschrift für Naturforschung 52c:267-269.

MONJE, P.V. \& BARAN, E.J. 2002. Characterization of calcium oxalates generated as biominerals in cacti. Plant Physiology 128:707-713.

MONJE, P.V. \& BARAN, E.J. 2004. Plant biomineralization. In Advances in plant physiology (H. Hemantaranjan, ed.). Scientific Publishers, Jodhpur, v.7. p.395-410.

PERRY, C.C. 1989. Chemical studies of biogenic silica. In Biomineralization - chemical and biochemical perspectives (S. Mann, J. Webb \& R.J.P. Williams, eds.). Verlag Chemie, Weinheim, p.223-256.

PERRY, C.C. 2003. Silicification: the process by which organisms capture and mineralize silica. In Reviews in mineralogy \& geochemistry 54. Biomineralization (P.M. Dove, J.J. De Yoreo \& S. Weiner, eds.). Mineralogical Society of America, Washington D.C., p.291-327.

ROLLERI, C.H. 1993. Revision of genus Christensenia. American Fern Journal 83:3-19.

ROLLERI, C.H. 2002. Caracteres diagnósticos y taxonomía del género Angiopteris Hoffm.(Marattiaceae) I. Los caracteres. Revista Museo La Plata, Botánica 15: 23-49.

ROLLERI, C.H. 2003. Caracteres diagnósticos y taxonomía del género Angiopteris Hoffm. (Marattiaceae) II. Sinopsis de las especies. Revista Museo de La Plata, Botánica 16:1-47. 
ROLLERI, C.H., DEFERRARI, A.M. \& CICCIARELLI, M. 1987. Epidermis y estomatogénesis en Marattiaceae (Marattiales). Revista Museo La Plata, Botánica 14: 124-147.

ROLLERI, C.H., DEFERRARI, A.M. \& LAVALLE, M.C. 1991. Epidermal morphology of the pinnae of Angiopteris, Danaea and Marattia. American Fern Journal 81:44-62.
ROLLERI, C.H., LAVALLE, M.C., MENGASCINI, A. \& RODRIGUEZ, M. 2003. Sistemática de helechos eusporangiados (Marrattiaceae-Marattiales). Revista Museo La Plata, Botánica 16:49-64.

ROLLERI, C.H., LAVALLE, M.C., MENGASCINI, A. \& RODRIGUEZ, M. 2004. Idioblastos de ópalo en helechos maratiáceos. Physis (Buenos Aires) C 59:13-21.

ROSS, S.D. 1972. Inorganic infrared and Raman spectra, McGraw-Hill, London. 